\title{
Financial Literacy Needs Of South African Third-Year University Students
}

Jurgens Louw, North-West University, South Africa

Jaco Fouché, North-West University, South Africa

Merwe Oberholzer, North-West University, South Africa

\begin{abstract}
It is evident from the literature that financial education and financial training fail in South Africa, which results in tertiary institutions sending their students into the world with a lack of preparedness for the financial challenges that await them. The problem with this study is that before interventions can be designed, a thorough understanding of the needs of students is important. Therefore, the purpose of this case study is to evaluate the financial literacy needs of third-year students at a South African university. The research fulfills the purpose by means of a survey, where a questionnaire was developed to first evaluate the socio-economic environment and exposure to the world of finance and then the financial literacy of 424 students who participated in this study. The contribution of this study is, first, that with the existing literature as a basis and a cluster analysis of the results, a new suitable questionnaire to evaluate financial literacy was developed for the South African context. Furthermore, the study uncovered the areas where the respondents, who are mainly financially supported by their parents, have a high level of literacy, as well as the areas of illiteracy that need to be addressed.
\end{abstract}

Keywords: Financial Literacy; Financial Capability; Financial Education; University Students; Personal Financial Management

\section{INTRODUCTION}

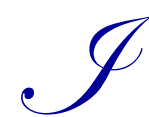

$\mathrm{n}$ recent times, financial literacy has gained the attention of a wide range of interested parties, such as major banking companies, government agencies, grass-root consumers and community interest groups (ANZ Banking Group, 2003; FSA, 2004; NCEE, 2005; Department of Education, 2002; OECD, 2005). These interested parties, including policymakers, are concerned that financial illiteracy may be affecting people's economic well-being since individuals do not have the tools they need to make appropriate financial decisions. This can leave a person vulnerable, resulting in severe financial crises (Braunstein \& Welch, 2002). Chen and Volpe's (1998) conclusion was that college students do not have adequate knowledge about personal finance and that these students are likely to make mistakes in the real world. According to Swart (2005), financial education and financial training fail in South Africa, which results in South African tertiary institutions sending their students into the world with a lack of preparedness for the financial challenges that await them. This case study reports the results of a survey that investigated the financial literacy of third-year students at a South African university within the context of their socio-economic environment and exposure to the world of finance. The logic of the study follows a route of a quantitative analysis of empirically collected primary data in this regard. The reason for using only third-year students is that they are in their final year and have gone through the university educational system and most of them will be pursuing a career in the nearby future. The importance of the study is that the areas of financial illiteracy are uncovered, providing an indication of the training needs in the South African educational system.

Although financial literacy is a new concept (Kempson et al., 2006), it is becoming more important for people to acquire and manage economic expertise (Lusardi \& Mitchell, 2007). As this is the case, there is a need for more financially capable people. In practice, there is, however, widespread financial illiteracy as many people are unfamiliar with the most basic economic concepts (Lusardi \& Mitchell, 2007). Many previous studies have been done in this regard and the most prominent disadvantages associated with being financially illiterate seem to be 
inability to interpret financial information (FSA, 2004; Braunstein \& Welch, 2002; Moore, 2003; Agnew \& Szykman, 2005), over-confidence (Lusardi \& Mitchellm, 2007; OECD, 2005; Chen \& Volpe, 1998), overindebtedness and not understanding the effects of compound interest (Lusardi \& Mitchell, 2007; Moore, 2003; Bristol et al., 2003), a lack in planning for the future (Braunstein \& Welch, 2002; Taylor, 2006; Mandell, 2005; Clark et al., 2005), and bankruptcy (American Bankruptcy Institute, 2001; Braunstein \& Welch, 2002). The abovementioned is an indication that the topic of financial literacy is one that has been written about extensively and even speculated about. Previous studies also pointed out the level of financial literacy in specific countries; for example, USA studies by Leyes (2006), NCEE (2005) and Chen and Volpe (1998), a UK study by Miles (2004), a European study by Christelis et al. (2005), and, on the other side of the Pacific, a Japanese study by Lusardi and Mitchel (2007). Therefore, it is evident that the lack of financial literacy skills is not an isolated problem. The 2004 FinMark Trust's (2005) FinScope survey of financial service providers that investigated consumer financial literacy concluded that these findings were no different in South Africa. To summarise, the previous studies found that most studies about financial literacy come to the same conclusion; i.e., that financial literacy levels are low and that they are not improving (Mandell, 2005).

With the backdrop of financial illiteracy and knowing that not much is being done to improve these literacy levels, the academics of South Africa would be ignorant not to pay any attention to this problem. After all, universities have always acknowledged their responsibility in terms of community service and development. Therefore, the problem of the study is that before interventions can be designed, a thorough understanding of the needs of students is important. Therefore, to fill this knowledge gap, the purpose of the study is to evaluate the 1) socio-economic environment and exposure to the world of finance and 2) the financial literacy of third-year students at a South African university. The research fulfills the purpose by means of a survey, where a questionnaire was developed to better understand some aspects of the socio-economic environment and exposure to the world of finance and the lack of knowledge among these students that has the potential to result in numerous financial problems associated with being financially illiterate. After analyzing the results of the financial knowledge questions, they were grouped into four clusters.

The contribution of this study is, first, that with the existing literature as a basis and a cluster analysis of the results, a new suitable questionnaire to evaluate financial literacy was developed for the South African context. Furthermore, the study uncovered the areas where the respondents, who are mainly financially supported by their parents, have a high level of literacy, as well as the areas of illiteracy that need to be addressed.

The next section provides a background to the study, followed by sections that explain the theory to develop the questionnaire and the research methodology, a section that reveals the findings, a summarization of the study, a discussion, and a conclusion.

\section{BACKGROUND}

\section{Conceptual Scope And Definition}

Although financial literacy is a new concept, it is becoming more important for people to acquire and manage economic expertise. In practice, there is, however, widespread financial illiteracy, as many people are unfamiliar with the most basic economic concepts. Not being familiar with basic economic concepts can have a number of adverse implications (Lusardi \& Mitchell, 2007). Defining financial literacy can be rather difficult since there are a number of definitions associated with the term financial literacy/capability. After analyzing various definitions (Kempson et al., 2006; Vitt et al., 2005; OECD, 2005), this concept was defined for this study as follows: A financially literate individual should have a positive attitude toward his/her (personal) finances and learning, the understanding to take control of his/her own finances, the ability to discern good from bad financial decisions, and the skills to make it practical. In this study, 'financial literacy' points to the broader financial skills and reference to 'personal finances' indicates matters pertaining specifically to an individual's personal finances. 


\section{Literature Review}

As seen in the introduction, the topic of financial literacy is one that has been written about extensively and even speculated about, but very little research, apart from countries such as the United States, the United Kingdom, Europe and Japan, has been done to measure the financial literacy of people in different countries. This literature review indicates the degree of financial illiteracy uncovered by research done in these countries.

A study quizzed 1,000 participants in the USA on important financial information (such as saving and investing, risk and protection, and retirement) that will affect their futures; most were unable to get 60 percent of the questions correct (Leyes, 2006). According to Miles (2004), UK borrowers display a weak understanding of mortgages and interest rates. Christelis et al. (2005) also documented that respondents in several European nations scored low on financial numeracy and literacy scales. A Japanese consumer finance enquiry showed that 71 percent of adult respondents knew little about equity and bond investments and more than 50 percent lacked any knowledge critical for effective saving plans (as quoted by Lusardi \& Mitchel, 2007). According to another survey, conducted for the NCEE (2005), nearly all US adults believe that it is important to have a good understanding of economics. However, despite this goal, the evidence shows that actual financial knowledge was deficient for both high school students and working-age adults. The survey consisted of a 24-item questionnaire on topics grouped into categories, including 'Economics and the consumer', 'Money, interest rates and inflation', and 'Personal finance'. When results were tallied using standard grading criteria, adults had an average score of $\mathrm{C}$, while the high school population scored an F. Particularly troublesome were the sections dealing with money, interest rates, inflation, government and trade, and personal finance. The 2004 FinMark Trust's (2005) FinScope survey of financial service providers with regard to consumer financial literacy in South Africa found that 45 percent of respondents who had a bank account said that they are confused about financial matters.

Another study, specifically focused on the youth, was done by Chen and Volpe (1998) among 924 college students. This study was done to examine students' knowledge of personal finance. The results from this survey show that college students need to improve their knowledge pertaining to personal finance. The mean scores for areas of general knowledge, savings and borrowing, insurance, and investment in the survey were below 65 percent, which shows that college students' knowledge of personal finance is inadequate. The weakest area for most of the college students was investments. Chen and Volpe (1998) concluded that college students do not have adequate knowledge about personal finance and that it is important to improve students' knowledge about personal finance since there is a lack of personal finance education in America's public schools. Miles (2004) also concluded that younger people - those in low social classes and those with low incomes - were the least sophisticated financial consumers. Therefore, it seems that education world-wide fails to equip future generations with the needed financial literacy skills. According to Swart (2005), the solution is very simple - compulsory personal financial literacy and management components in all tertiary syllabi.

\section{Summary Of Argument And Open Question}

Previous studies indicated that financial illiteracy is a fact. Flowing from the literature study, it is clear that there is a lack of financial literacy among young people and this has the potential to result in numerous financial problems associated with being financially illiterate. The lack of financial literacy seems to be the result of inadequate education. This raises a number of important questions, such as "What is the exposure to financial practices of university students?", "What knowledge do university students possess about financial literacy?", and "Is the knowledge that university students have about financial literacy sufficient for their future?"

\section{THEORY}

Many sources on personal finance are available to educate individuals about personal finance in order to become financially literate. In this part of the study, the literature, consisting of books, university courses and research studies, will be investigated to determine the content of personal finance. After reviewing the contents of the books, courses and what researchers found, matrixes will be drawn up to illustrate the findings. From these matrixes, it is possible to identify a comprehensive topic list that was the basis for the newly developed questionnaire. Tables 1,2 and 3 exhibit the topic list from seven books, three university courses and what researchers (six) found important, respectively. 
Table 1: Comparison Of Books Reviewed

\begin{tabular}{|l|c|c|c|c|c|c|c|}
\hline \multicolumn{1}{|c|}{ Books* } & Ma & Sw & Mc & Mi & Hu & W \& F & K, D \& H \\
\hline Financial planning & $\mathrm{X}$ & & & $\mathrm{X}$ & $\mathrm{X}$ & $\mathrm{X}$ & $\mathrm{X}$ \\
\hline Budgeting & $\mathrm{X}$ & $\mathrm{X}$ & $\mathrm{X}$ & $\mathrm{X}$ & $\mathrm{X}$ & $\mathrm{X}$ & $\mathrm{X}$ \\
\hline Cash & $\mathrm{X}$ & & & & & $\mathrm{X}$ & \\
\hline Credit / Debt & $\mathrm{X}$ & $\mathrm{X}$ & $\mathrm{X}$ & $\mathrm{X}$ & & $\mathrm{X}$ & $\mathrm{X}$ \\
\hline Housing & $\mathrm{X}$ & $\mathrm{X}$ & & $\mathrm{X}$ & & $\mathrm{X}$ & $\mathrm{X}$ \\
\hline Insurance & $\mathrm{X}$ & $\mathrm{X}$ & $\mathrm{X}$ & $\mathrm{X}$ & $\mathrm{X}$ & $\mathrm{X}$ & $\mathrm{X}$ \\
\hline Investment & $\mathrm{X}$ & $\mathrm{X}$ & $\mathrm{X}$ & $\mathrm{X}$ & $\mathrm{X}$ & $\mathrm{X}$ & $\mathrm{X}$ \\
\hline Retirement & $\mathrm{X}$ & $\mathrm{X}$ & $\mathrm{X}$ & $\mathrm{X}$ & $\mathrm{X}$ & $\mathrm{X}$ & $\mathrm{X}$ \\
\hline Estate planning & $\mathrm{X}$ & $\mathrm{X}$ & $\mathrm{X}$ & $\mathrm{X}$ & $\mathrm{X}$ & $\mathrm{X}$ & $\mathrm{X}$ \\
\hline Taxes & & $\mathrm{X}$ & $\mathrm{X}$ & & $\mathrm{X}$ & $\mathrm{X}$ & $\mathrm{X}$ \\
\hline Career planning & & $\mathrm{X}$ & & & & $\mathrm{X}$ & $\mathrm{X}$ \\
\hline Health planning/insurance & & $\mathrm{X}$ & & $\mathrm{X}$ & $\mathrm{X}$ & $\mathrm{X}$ & $\mathrm{X}$ \\
\hline Savings & & & & & $\mathrm{X}$ & & \\
\hline Consumerism & & & & & $\mathrm{X}$ & & \\
\hline Personal finance - day-to-day financial activities & & & $\mathrm{X}$ & $\mathrm{X}$ & & $\mathrm{X}$ & $\mathrm{X}$ \\
\hline Expenditure & & & & $\mathrm{X}$ & $\mathrm{X}$ & $\mathrm{X}$ & $\mathrm{X}$ \\
\hline Financial statements/record keeping & & $\mathrm{X}$ & $\mathrm{X}$ & & $\mathrm{X}$ & $\mathrm{X}$ & $\mathrm{X}$ \\
\hline Financial institutions & & & $\mathrm{X}$ & & & \\
\hline Productivity planning & & $\mathrm{X}$ & & & & $\mathrm{X}$ \\
\hline
\end{tabular}

$* \mathrm{Ma}=$ Mathur, 1989, Personal finance .

$* \mathrm{Sw}=$ Swart, 1996, Personal finance management .

$* \mathrm{Mc}=\mathrm{McRea}, 1997$, Managing your own finances .

* Mi = Mittra, 1977, Personal finance: lifetime management objectives.

$* \mathrm{Hu}=$ Hurley, 1976, Personal money management: A consumer guide.

$* \mathrm{~W} \& \mathrm{~F}=$ Winger and Frasca, 1993, Personal finance: An integrated planning approach .

*K,D\&H = Kapoor, Dlabay and Hughes, 1991, Personal finance.

Table 2: Comparison Between Local Universities

\begin{tabular}{|c|c|c|c|}
\hline Local University Courses & $\begin{array}{c}\text { UNISA } \\
\text { B F L S* }\end{array}$ & $\begin{array}{l}\text { UNISA } \\
\text { P F M* }\end{array}$ & $\begin{array}{c}\text { North-West University } \\
\text { P F M }\end{array}$ \\
\hline Financial planning & $\mathrm{X}$ & & \\
\hline Budgeting & $\mathrm{X}$ & & $\mathrm{X}$ \\
\hline Credit / Debt & $\mathrm{X}$ & & $\mathrm{X}$ \\
\hline Budgeting - Buying a car & $\mathrm{X}$ & & \\
\hline Housing & $\mathrm{X}$ & & $\mathrm{X}$ \\
\hline Investment & $\mathrm{X}$ & $\mathrm{X}$ & $\mathrm{X}$ \\
\hline Insurance & $\mathrm{X}$ & $\mathrm{X}$ & $\mathrm{X}$ \\
\hline Retirement & $\mathrm{X}$ & $\mathrm{X}$ & \\
\hline Career planning & $\mathrm{X}$ & $\mathrm{X}$ & $\mathrm{X}$ \\
\hline Starting a business & $\mathrm{X}$ & $\mathrm{X}$ & \\
\hline Banking & $\mathrm{X}$ & & $\mathrm{X}$ \\
\hline Choosing a broker & & $\mathrm{X}$ & \\
\hline Financial risk & & $\mathrm{X}$ & \\
\hline Taxes & & $\mathrm{X}$ & \\
\hline Estate & & $\mathrm{X}$ & \\
\hline Ante-nuptial contracts & & $\mathrm{X}$ & \\
\hline Emigration & & $\mathrm{X}$ & \\
\hline
\end{tabular}

*B F L S = Basic Financial Life Skills

*P F M = Personal Financial Management 
Table 3: Comparison Between Researchers

\begin{tabular}{|l|c|c|c|c|c|c|}
\hline \multicolumn{1}{|c|}{ Researchers* } & FSA & ANZ & F & C \& V & M & Fin \\
\hline Keeping record & $\mathrm{X}$ & $\mathrm{X}$ & $\mathrm{X}$ & $\mathrm{X}$ & & \\
\hline Credit & $\mathrm{X}$ & $\mathrm{X}$ & & $\mathrm{X}$ & $\mathrm{X}$ \\
\hline Planning ahead (budget) & $\mathrm{X}$ & $\mathrm{X}$ & $\mathrm{X}$ & $\mathrm{X}$ & $\mathrm{X}$ & $\mathrm{X}$ \\
\hline Retirement planning & $\mathrm{X}$ & $\mathrm{X}$ & & $\mathrm{X}$ & $\mathrm{X}$ & $\mathrm{X}$ \\
\hline Financial planning & $\mathrm{X}$ & $\mathrm{X}$ & & & & $\mathrm{X}$ \\
\hline Financial products\# & $\mathrm{X}$ & $\mathrm{X}$ & & & $\mathrm{X}$ & $\mathrm{X}$ \\
\hline Investments and savings & $\mathrm{X}$ & $\mathrm{X}$ & $\mathrm{X}$ & $\mathrm{X}$ & $\mathrm{X}$ & $\mathrm{X}$ \\
\hline
\end{tabular}

\# Include various products such as insurance, included health insurance, retirement planning and general banking.

*FSA = Financial Services Authority (2002)

$*$ ANZ = ANZ Banking Group (2003)

$* \mathrm{~F}=$ Feeny $(2006)$

$* \mathrm{C} \& \mathrm{~V}=$ Chen and Volpe (1998)

$* \mathrm{M}=$ Moore (2003)

$*$ Fin $=$ FinScope $(2004)$

Tables 1, 2 and 3 set the basis to compile a comprehensive topic list. A summary of all the topics that are covered by books, courses and research is exhibited in a matrix form in Table 4. A questionnaire to determine the financial literacy (knowledge) is developed from Table 4. The five topics that are covered by all three sources were regarded as the most important and three questions were developed for each of them (15 questions). The nine topics that are covered by two of the three sources were regarded as the second most important and two questions were developed for each of them (18 questions). The remaining nine topics that are covered in only one of the sources were regarded as the less important and only a single question was developed for each of them (nine questions). In total, the questionnaire for financial knowledge consists of 42 questions. As a result of space restriction, the questions are shown only in the presentation of the results in Tables 6 through 9.

Table 4: Comparison Between Topics Found In Books, Courses And Research

\begin{tabular}{|c|c|c|c|}
\hline 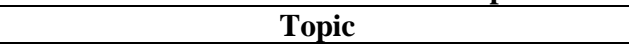 & Books & University Courses & Researchers \\
\hline Financial planning & $\mathrm{X}$ & $\mathrm{X}$ & $\mathrm{X}$ \\
\hline Budgeting & $\mathrm{X}$ & $\mathrm{X}$ & $\mathrm{X}$ \\
\hline Cash & $\mathrm{X}$ & - & - \\
\hline Credit / Debt & $\mathrm{X}$ & $\mathrm{X}$ & $\mathrm{X}$ \\
\hline Housing & $\mathrm{X}$ & $\mathrm{X}$ & - \\
\hline Insurance & $\mathrm{X}$ & - & $\mathrm{X}$ \\
\hline Investment & $\mathrm{X}$ & $\mathrm{X}$ & $\mathrm{X}$ \\
\hline Retirement & $\mathrm{X}$ & $\mathrm{X}$ & $\mathrm{X}$ \\
\hline Estate planning & $\mathrm{X}$ & $\mathrm{X}$ & - \\
\hline Taxes & $\mathrm{X}$ & $\mathrm{X}$ & - \\
\hline Career planning & $\mathrm{X}$ & $\mathrm{X}$ & - \\
\hline Health planning/insurance & $\mathrm{X}$ & - & $\mathrm{X}$ \\
\hline Savings & $\mathrm{X}$ & - & $\mathrm{X}$ \\
\hline Consumerism & $\mathrm{X}$ & - & - \\
\hline Personal finance - day-to-day financial activities & $\mathrm{X}$ & - & \\
\hline Expenditure & $\mathrm{X}$ & - & - \\
\hline Financial statements/record keeping & $\mathrm{X}$ & - & $\mathrm{X}$ \\
\hline Financial institutions & $\mathrm{X}$ & - & - \\
\hline Productivity planning & $\mathrm{X}$ & - & - \\
\hline Starting a business & - & $\mathrm{X}$ & - \\
\hline Banking & - & $\mathrm{X}$ & $\mathrm{X}$ \\
\hline Ante-nuptial contracts & - & $\mathrm{X}$ & - \\
\hline Emigration & - & $\mathrm{X}$ & - \\
\hline
\end{tabular}

\section{RESEARCH METHODOLOGY}

This study is done in the paradigm of the 'world of science and scientific research'. In the 'world of everyday life', the stock of knowledge (e.g. financial literacy) enables a person to cope with his/her daily tasks. The 
'world of science and scientific research' aims to generate epistemic (truthful); i.e., valid and reliable descriptions of the everyday life (Maree, 2011). The empirical study was in the form of a questionnaire that allows for analyses that are descriptive; i.e., to find out more about students' daily exposure to financial practices and their levels of financial literacy and to capture it with detail (Wisker, 2001). The questionnaire consists of two parts - first, evaluating some aspects of the students' socio-economic environment and exposure to financial practices and second, evaluating their personal finance knowledge.

\section{Sampling}

This research focused only on third-year students since they have gone through the university educational system and most of them will be pursuing a career in the nearby future. The population was grouped according to the faculties of the University as follows: Arts, including Theology; Economic and Management Sciences; and Natural Sciences, including Engineering and Health Sciences. Deans were requested to identify the module that represents most of those faculties' students, i.e. this is purposeful sampling. The questionnaires were then given to the appropriate lecturer for completion by the students. Participation was voluntary and anonymous.

\section{Survey Validity}

To ensure validity, before pilot testing, the questionnaire was first reviewed by the Statistical Consultation Service of the North-West University (Potchefstroom Campus) to ensure that the questionnaire met the required statistical standards. After the pilot test, certain changes were made to the questionnaire to ensure its effectiveness. Finally, the questionnaires were completed by the sample group and were analyzed using the SAS computer software (SAS Institute Inc., 2003-2005).

\section{ANALYSIS OF RESULTS}

The results are presented as the financial literacy profiles and the financial literacy knowledge of the respondents. In total, 424 students (37\% male and 63\% female) from Arts (24\%), Economic and Management Sciences (60\%), and Natural Sciences (16\%) completed the questionnaire.

\section{Profile of Socio-economic Environment And Exposure To Financial Practices}

Ten general questions were posed to the participants to better understand their socio-economic environment and exposure to the world of finance (Table 5). The respondents could either choose 'yes' or 'no' as their answers to these questions.

Table 5: Profile of Socio-economic Environment And Exposure To Financial Practices

\begin{tabular}{|c|c|c|c|}
\hline No. & Question & Yes $(\%)$ & No $(\%)$ \\
\hline 1 & Do you have loans or any other debt? & 39 & 61 \\
\hline 2 & Do you know how you will be earning a living next year? & 60 & 40 \\
\hline 3 & Are you able to prepare your own will according to the minimum legal requirements? & 27 & 73 \\
\hline 4 & Do you have any investments? & 37 & 63 \\
\hline 5 & Do you budget for your day-to-day finances? & 56 & 45 \\
\hline 6 & Do you think that retirement is too far away to think about it right now? & 36 & 64 \\
\hline 7 & Do you keep track of your daily spending? & 67 & 33 \\
\hline 8 & Do you have a credit card or store card? & 32 & 68 \\
\hline 9 & Do you have a part-time job? & 24 & 76 \\
\hline 10 & Do your parents still support you financially? & 90 & 10 \\
\hline
\end{tabular}

From Table 5, it was evident that various personal financial elements were present in the students' lives. These include debt, investments and short-term budgeting. The fact that 90 percent of the students said they are financially supported by their parents is supported by the answers that the majority do not have debt $(61 \%)$, investments $(63 \%)$, a credit/store card, or a part-time job (76\%). Furthermore, the majority do not know how to prepare a will (73\%) and 36 percent think retirement is too far away to think about. On the other hand, the majority (60\%) know how they will earn a living next year, but it is also alarming that many students (40\%) did not know 
how they would earn a living after leaving university. It seems that cash management is important for the students since the majority budget for their day-to-day finances (56\%) and keep track of their daily spending (67\%).

\section{Personal Finance Knowledge}

This section consists of 42 questions posed to the participants. The questions were marked as 'correct' and 'incorrect'. Participants also had the option to choose 'Do not know'. A factor analysis was carried out on the data, but because the data had 'right' and 'wrong' answers, the factor analysis did not show any significant similarities. In order to analyze the answers in sensible groups, a cluster analysis on binary data was then performed using a Sokal and Sneath distance measure for the binary data. The binary data were then divided into four clusters according to the cluster analysis. When comparing the cluster groups with the questions from the questionnaire, the following similarities were identified:

- $\quad$ Cluster 1 represents questions about General financial literacy questions

- $\quad$ Cluster 2 represents questions about Financial planning and investments

- $\quad$ Cluster 3 represents questions about Banking and taxation

- $\quad$ Cluster 4 represents question about Legal and sundry financial matters

Reliability tests were also performed on these questions to ensure the validity of the clusters. The Cronbach alphas of Clusters 1 to 4 are 0.74, 0.69, 0.30 and 0.54, respectively. The reason for calculating the Cronbach alphas was to determine whether the questions in a cluster form a sensible focus unit. This implies that Clusters 1,2 and 4 are sensible focus units since their Cronbach alphas are larger than 0.5, while Cluster 3's Cronbach alpha is smaller than 0.5 and therefore a less sensible unit. The results of the questions grouped into the clusters are provided below.

\section{General Financial Literacy}

Table 6 shows the percentage of respondents who answered the questions correctly, incorrectly or did not know the answer to the questions asked in this cluster about general financial literacy.

Table 6: General Financial Literacy

\begin{tabular}{|c|c|c|c|c|}
\hline No. & Detail & Correct \% & Incorrect \% & $\begin{array}{l}\text { Do not } \\
\text { know \% }\end{array}$ \\
\hline 2 & $\begin{array}{l}\text { Long-term financial goals should be changed as new information becomes } \\
\text { available. }\end{array}$ & 79 & 14 & 7 \\
\hline 3 & Setting short-term goals helps us to control our living expenses. & 91 & 5 & 4 \\
\hline 9 & $\begin{array}{l}\text { Two investments, namely A and B have the same level of risk associated } \\
\text { with them. A has a higher level of return than B. Therefore, B is the } \\
\text { preferred investment choice. }\end{array}$ & 76 & 9 & 15 \\
\hline 10 & A budget is a monetary expression of your financial priorities. & 83 & 5 & 12 \\
\hline 11 & Tax records should be kept for five years. & 75 & 8 & 17 \\
\hline 12 & Invoices of assets purchased should be kept for warrantee purposes. & 88 & 5 & 7 \\
\hline 16 & Inflation has an impact on savings. & 86 & 8 & 6 \\
\hline 18 & Debt is always a bad idea. & 65 & 30 & 5 \\
\hline 21 & All job openings are advertised in newspapers. & 89 & 8 & 3 \\
\hline 23 & $\begin{array}{l}\text { The 'tax year' normally stretches from } 1 \text { January until the last day in } \\
\text { December (the same year). }\end{array}$ & 79 & 9 & 12 \\
\hline 24 & A valid will does not have to meet legal requirements. & 79 & 11 & 11 \\
\hline 25 & Age plays a role in determining a person's car insurance. & 82 & 9 & 9 \\
\hline 32 & All banks charge the same service fees on cheque accounts. & 86 & 6 & 8 \\
\hline 37 & $\begin{array}{l}\text { If you are married in community of property both spouses must sign the } \\
\text { documents if you purchase a fixed property. }\end{array}$ & 67 & 13 & 20 \\
\hline 38 & $\begin{array}{l}\text { A statement of financial position shows your assets, liabilities and net worth } \\
\text { at a given date. }\end{array}$ & 78 & 6 & 16 \\
\hline \multirow[t]{2}{*}{40} & Certain healthcare/medical aid plans only pay for hospital expenses. & 80 & 8 & 12 \\
\hline & Average & 80 & 10 & 10 \\
\hline
\end{tabular}


From Table 6, it is evident that the section of general financial literacy was answered well overall. The majority of respondents answered all 16 questions correctly with an average of 80 percent. The fact that 30 percent of the respondents have the opinion that debt is always a bad idea is probably an indication of a conservative view to financing.

\section{Financial Planning And Investments}

Table 7 shows the percentage of respondents who answered the questions correctly, incorrectly or did not know the answer to the questions asked in the cluster about financial planning and investments.

Table 7: Financial Planning And Investments

\begin{tabular}{|c|c|c|c|c|}
\hline No. & Detail & Correct \% & Incorrect \% & $\begin{array}{l}\text { Do not } \\
\text { know \% }\end{array}$ \\
\hline 1 & Financial planning should not be affected by inflation. & 60 & 28 & 12 \\
\hline 4 & Fixed expenses remain fixed for many years. & 50 & 36 & 14 \\
\hline 8 & Return on most investments is guaranteed. & 63 & 23 & 14 \\
\hline 14 & A deposit slip is the document used to transfer money between accounts. & 36 & 54 & 11 \\
\hline 17 & The best way to save money is to save money in a savings account. & 53 & 35 & 12 \\
\hline 20 & $\begin{array}{l}\text { If you have car insurance and you have an accident your premium should } \\
\text { stay the same. }\end{array}$ & 58 & 26 & 16 \\
\hline 27 & Cash is a high return earning asset category. & 39 & 29 & 32 \\
\hline \multirow[t]{2}{*}{39} & $\begin{array}{l}\text { Consumer credit and credit cards are generally regarded as the least } \\
\text { expensive form of credit. }\end{array}$ & 44 & 27 & 28 \\
\hline & Average & 51 & 32 & 17 \\
\hline
\end{tabular}

Table 7 indicates that the majority of respondents could answer only five of the eight questions correctly, with an overall average of 51 percent. This is an indication that the students have limited knowledge about financial planning and investments.

\section{Banking And Taxation}

Table 8 shows the percentage of respondents who answered the questions correctly, incorrectly or did not know the answer to the questions asked in the cluster about banking and taxation.

Table 8: Banking And Taxation

\begin{tabular}{|c|c|c|c|c|}
\hline No. & Detail & Correct \% & $\begin{array}{c}\text { Incorrect } \\
\%\end{array}$ & $\begin{array}{l}\text { Do not } \\
\text { know \% }\end{array}$ \\
\hline 13 & $\begin{array}{l}\text { If you have a debit balance on your bank statement you have a positive } \\
\text { balance on your account. }\end{array}$ & 48 & 44 & 8 \\
\hline 15 & $\begin{array}{l}\text { If a person's net worth is } R 9000 \text { and the person owes } R 8000 \text {, the person } \\
\text { has total assets of } R 17000(R=R \text { and, SA currency). }\end{array}$ & 23 & 64 & 13 \\
\hline 22 & Every owner of a business must register for value-added tax. & 39 & 57 & 4 \\
\hline 26 & Compared to buying, renting a house provides more financial flexibility. & 46 & 32 & 22 \\
\hline 29 & The current maximum (marginal) tax rate for individuals is $40 \%$. & 50 & 17 & 33 \\
\hline 33 & $\begin{array}{l}\text { At the moment, a bond payment is generally more expensive than renting } \\
\text { the same property. }\end{array}$ & 16 & 39 & 45 \\
\hline \multirow[t]{2}{*}{36} & Retirement annuity fund contributions are tax deductible. & 58 & 15 & 27 \\
\hline & Average & 40 & 38 & 22 \\
\hline
\end{tabular}

Table 8 indicates that the majority of respondents could answer only two of the seven questions correctly, with an overall average of 40 percent. This is an indication that the students have very limited knowledge about this section. Since the Cronbach alpha is very low for this cluster, it is probably an indication of a low level of knowledge where answers (agree or disagree) were chosen haphazardly because no specific pattern exists in the answers. 


\section{Legal And Sundry Financial Matters}

Table 9 shows the percentage of respondents who answered the questions correctly, incorrectly or did not know the answer to the questions asked in the cluster about legal and sundry matters.

Table 9: Legal And Sundry Financial Matters

\begin{tabular}{|c|c|c|c|c|}
\hline No. & Detail & Correct \% & Incorrect \% & $\begin{array}{r}\text { Do not } \\
\text { know \% }\end{array}$ \\
\hline 5 & It is not necessary for budgeted and actual expenses to be equal. & 33 & 55 & 12 \\
\hline 6 & $\begin{array}{l}\text { You must register at the Department of Trade and Industry before you can } \\
\text { start your own business. }\end{array}$ & 16 & 59 & 24 \\
\hline 7 & The use of a credit can help during periods of high inflation. & 24 & 53 & 23 \\
\hline 19 & $\begin{array}{l}\text { A medical fund can turn you down if you applied to become a member of } \\
\text { the medical fund. }\end{array}$ & 18 & 61 & 21 \\
\hline 28 & The current inflation rate is between 10 and $11 \%$. & 29 & 36 & 35 \\
\hline 30 & The current prime lending rate is $15 \%$. & 15 & 41 & 44 \\
\hline 31 & $\begin{array}{l}\text { If you feel that you have been mistreated during a loan application you can } \\
\text { take the matter to the National Credit Regulator. }\end{array}$ & 59 & 8 & 33 \\
\hline 34 & $\begin{array}{l}\text { A general rule of thumb is that you will need } 10 \text { times your annual salary } \\
\text { in savings at retirement, to be able to retire financially independent. }\end{array}$ & 41 & 10 & 49 \\
\hline 35 & $\begin{array}{l}\text { If you have a complaint about your banking institution you can take the } \\
\text { matter to the Banking Ombudsman. }\end{array}$ & 42 & 10 & 48 \\
\hline 41 & $\begin{array}{l}\text { You need to have an ante-nuptial contract if you are married out of } \\
\text { community of property. }\end{array}$ & 43 & 8 & 49 \\
\hline \multirow[t]{2}{*}{42} & $\begin{array}{l}\text { If you emigrate there is a limit to the amount of money you can take out of } \\
\text { the country. }\end{array}$ & 51 & 23 & 26 \\
\hline & Average & 34 & 33 & 33 \\
\hline
\end{tabular}

Table 9 indicates that the majority of respondents could correctly answer two questions out of 11, with an overall average of 34 percent. This is an indication that the students have extremely limited knowledge about legal and sundry financial matters.

\section{DISCUSSION AND CONCLUSION}

This case study investigated the financial literacy needs of third-year students at a South African university. Ten questions were included in the questionnaire to determine some aspects of the students' socio-economic environment and their exposure to financial practices and another 42 questions were included to evaluate their personal financial knowledge. In total, 424 students completed the questionnaire.

The first question asked, "What is the exposure to financial practices of university students?" The study found that 90 percent of the students indicated they are financially supported by their parents, which is supported by the answers that the majority do not have debt, investments, a credit/store card, or a part-time job. The majority does also not know how to prepare a will and a substantial number think retirement is too far away to think about. Furthermore, it seems that cash management is important for the students since the majority budget for their day-today finances and keep track of their daily spending. From this finding, the conclusion can be drawn that the students operate in a highly protected socio-economic environment and do not have much exposure to financial practices since it seems that their parents take the responsibility for financial issues. The only responsibility of the students is to manage the less complicated part; namely, cash transactions.

The second question asked, "What knowledge do university students possess about financial literacy?" The study found that, although the students do not have much exposure with financial practices, they have a good level of knowledge regarding the cluster questions on general financial literacy. This is probably because 60 percent of the respondents are students from the Faculty of Economic and Management Sciences. On the other hand, low to extremely low levels of knowledge exist regarding the clusters of financial planning and investments, banking and taxation, and legal and sundry matters. This finding is also in line with some previous research that indicated there are several topics that are identified as problem areas, such as investments (Lusardi \& Mitchell, 2007; Chen \& 
Volpe, 1998), interest rates (Miles, 2004; NCEE, 2005), inflation, and government and trade (NCEE, 2005). These three clusters are probably more specialized topics, but from the findings, this study concludes that students need more training in the latter three clusters.

The third question asked, "Is the knowledge that university students have about financial literacy sufficient for their future?" With the evidence that the students could, on average, only score 51, 40 and 34 percent for the questions in these latter cluster groups leads to the conclusion that their financial literacy regarding to these groups is not sufficient.

The contribution of this study is, first, that with the existing literature as basis and cluster analysis, a new suitable questionnaire to evaluate financial literacy was developed for the South African context. Furthermore, the study uncovered that students' needs are training in the areas of financial planning and investments, banking and taxation, and legal and sundry matters. The question remains as to whose responsibility it is to provide this training. Therefore, the practical implication is that the university can either ignore this shortcoming or it may take the responsibility to support students with adequate training in this regard.

Although this is a case study, with the limitation that the results are only valid for the student at the university that was investigated and generalization should be done with great care, the value is that this was the first effort to investigate the financial literacy of university students at a South African university within the context of their socio-economic environment and exposure to the world of finance. The originality of the study is the newly developed questionnaire that can be used as a basis to do further similar comparative investigations at other tertiary institutions. This will alleviate the limitation of the study, which investigated only the case of a single South African university. Furthermore, another limitation is that the results were not analyzed separately according to the faculty groups of Arts, Economic and Management Sciences and Natural Sciences. Further studies should be done to determine whether there is a significant difference between the financial literacy scores between the various faculties.

\section{AUTHOR INFORMATION}

Jurgens Louw is financial manager at Free State Maize and is a registered Professional Accounting. He completed recently a master's degree in financial management at the North-West University (South Africa).

Professor Jaco Fouché is currently professor in the School of Accounting Sciences at the North-West University (South Africa). He holds the Chartered Accountant (CA (SA)) designation and has taught extensively in the Chartered Accountancy program and is currently Director of the School of Accounting Sciences. His current research focuses mainly on Accounting Education and Personal Financial Wellness.

Professor Merwe Oberholzer is currently professor in the School of Accounting Sciences at the North-West University (South Africa). He has taught extensively in the Chartered Accountancy and Chartered Management Accountancy programs. His academic research output includes more than 40 peer-reviewed articles and conference presentations. His current research focuses mainly on corporate resilience, -sustainability and DEA modeling. E-mail: Merwe.Oberholzer@nwu.ac.za (Corresponding author)

\section{REFERENCES}

1. Agnew, J. \& Szykman, L. (2005). Asset Allocation and Information Overload: The Influences on Information Display, Asset Choices and Investors Experience. Retrieved from http://web.ebscohost.com/ehost/pdf?vid=1\&hid=117\&sid=64452f31-d80e-4f3d-b2bbc7f96511670b\%40sessionmgr106

2. American Bankruptcy Institute. (2001). US Bankruptcy Fillings 1980-2001. Retrieved from http://www.abiworld.org/stats/1980annaul.html

3. ANZ Banking group. (2003). ANZ survey of adult financial literacy in Australia. Melbourne: Ray Morgan.

4. Braunstein, S. \& Welch, C. (2002). Financial Literacy: An Overview of Practice, Research, and Policy. Federal Reserve Bulletin, 445-457, November. 
5. Bristol, K., Fehr, D. \& Tripp, G. (2003). Using an Academic Trading Room to Enhance Economics Literacy Training. Retrieved from http://www.snhu.edu/files/pdfs/EconomicsLiteracy.pdf

6. Chen, H. \& Volpe, R.P. (1998). An Analysis of Personal Financial Literacy among College Students. Financial Services Review, 7(2):107-128.

7. Christelis, D., Jappelli, T. \& Padula, M. (2005). Health Risk, Financial Information and Social Interaction: The Portfolio Choice of European Elderly Households. Retrieved from http://www.csef.it/1st_C6/cjp_June16.pdf

8. Clark, R.L., D’Ambrosio, M.B. \& McDermed, A.A. (2003). Financial Education and Retirement Savings. Retrieved from http://www.jumpstartcoalition.org/upload/Mandell\%20Paper\%20April\%202005.doc

9. Department of Education. (2002). Revised National Curriculum Statement Grade R - 9 (Schools) Economics and Management Sciences. Retrieved from http://www.education.gov.za/Curriculum/Get/doc/economic.pdf

10. Feeny, T. (2006). Beyond budgeting to financial literacy: An Evaluation of the Smith Family's MoneyMinded Program. Sydney: The Smith Family.

11. FinScope. (2004). Survey Highlights. Retrieved from http://www.finscope.co.za/documents/2004/SA2004Brochure.pdf

12. Financial Services Authority (FSA). (2002). Personal finance teaching in schools. United Kingdom. Retrieved from http://www.fsa.gov.uk/consumer-research/crpr11.pdf

13. Financial Services Authority (FSA). (2004). Young people and their financial matters. United Kingdom. Retrieved from http://www.fsa.gov.uk/pubs/consumer-research/CRPR25.pdf

14. FinMark Trust. (2005). Preliminary Principles for Expanding Consumer Financial Literacy In SA. Retrieved from http://www.finmarktrust.org.za/documents/2006/FEBRUARY/C_CFinLit.pdf

15. Hurley, G.E. (1976). Personal money management: A consumer guide. New Jersey: Prentice-Hall.

16. Kapoor, J.R., Dlabay, L.R. \& Hughes, R.J. (1991). Personal finance. Boston: Irwin.

17. Kempson, E., Collard, S. \& Moore, N. (2006). Measuring Financial Capability: An Exploratory Study for the Financial Services Authority. (In: Consumer Financial Capability: Empowering European Consumers., eds. Brussels: European Credit Research Institute)

18. Leyes, M. 2006. Failing Grade on Financial Literacy. Advisory Today: 36, Jul.

19. Lusardi, A. \& Mitchell, O.S. (2007). Financial Literacy and Retirement Preparedness: Evidence and Implications for Financial Education. Business Economics, 42(1):35-44.

20. Mandell, L. (2005). Financial Literacy: Does It Matter? Retrieved from gwbweb.wustl.edu/csd/Publications/2006/WP06-11.pdf

21. Mathur, I. (1989). Personal finance. $2^{\text {nd }}$ ed. Cincinnati: South-Western.

22. Maree, K. (Editor). (2011). First steps in research. Pretoria: Van Schaik.

23. McRae, T.W. (1997). Managing your own finances. London: Thomson.

24. Miles, D. (2004). The UK Mortgage Market: Taking a Longer Term View. Retrieved from www.hmtreasury.gov.uk/media/3/c/miles04-470[1].pdf

25. Mittra, S. (1977). Personal finance: Lifetime management by objectives. New York: Harper \& Row.

26. Moore, D. (2003). Survey on Financial Literacy in Washington State: Knowledge, Behaviour, Attitudes and Experiences. Retrieved from http://www.dfi.wa.gov/news/finlitsurvey.pdf

27. National Council on Economic Education (NCEE). (2005). What American Teens \& Adults Know About Economics. Retrieved from http://207.124.141.218/WhatAmericansKnowAboutEconomics 042605-3.pdf

28. Organization for Economic Co-operation and Development (OECD). (2005). Improving financial literacy: Analysis of issues and policies. Paris: OECD Publishing.

29. SAS Institute Inc. (2003). The SAS System For Windows Release 9.1 TS Level 1M3 Copyright@ by SAS Institute Inc., Cary, NC, USA

30. Swart, N. (1996). Personal financial management. Cape Town: Juta.

31. Swart, N. (2005). Why Financial Literacy Is A Complete Failure. Management Today: 48-50, May.

32. Taylor, M. (2006). Financial Literacy: Ignorance Is Not Bliss. Money Management: 4-15, Jul.

33. Vitt, L.A., Reichbach, G.M. \& Siegenthaler, J.K. 2005. Goodbye to Complacency - Financial Literacy Education in the U.S 2000 - 2005. Retrieved from http://www.isfs.org/GoodbyetoComplacencynocover.pdf

34. Winger, B.J. \& Frasca, R.R. (1993). Personal finance: An integrated planning approach. $3^{\text {rd }}$ ed. New York: Macmillan. 
35. Wisker, G. (2001). The postgraduate research handbook: Succeed with your MA, MPhil, EdD and PhD. $2^{\text {nd }}$ ed. New York: Palgrave Macmillan.

\section{NOTES}

